\title{
Effect of Carbonation on Mechanical Properties \& Durability of Concrete with Replacement of Sand by Pond Ash
}

\author{
Dr. Rajesh Kumar Tripathi, Sri Ram Krishna Mishra
}

\begin{abstract}
Effect of carbonation on mechanical properties and durability of concrete has been studied in this work. Concrete has been prepared using ordinary Portland cement as binder with water/binder ratio $0.45,0.50$ and 0.55 . Compressive strength \& electrical resistivity test have been preformed for noncarbonated \& carbonated samples. Natural sand has been replaced with industrial by product (fly ash) for sustainable construction. All results have been compared with standard results available. Carbonation test indicates on improvement of strength and electrical resistivity.
\end{abstract}

Keywords: Compressive strength, electrical resistivity, accelerated carbonation testing method, lastingness

\section{INTRODUCTION}

$\mathrm{P}$ onded ash (PA) is waste product of thermal power plant, obtained as wet disposal of fly ash. Its major constituents are $\mathrm{CaO}, \mathrm{MgO}$ and $\mathrm{SO}_{3}$. Large land areas, near thermal power plants degraded due to its dumping. Ponded ash proved as sand replacement for sustainable and durable construction up to $50 \%$ replacement level [1, 2, 3, and 4]. It is also observed that use of PA as fine aggregate replacement improves shrinkage properties in fresh and hardened state [5]. Ponded ash can be treated as low reactive material which loses its pozzolanacity and hence suitable as fine aggregate replacement [6]. Carbonation improves the mechanical properties of concrete and reduces the chloride ion permeability but increases the corrosion rate of rebar in reinforced concrete structures (RCC) [7]. Corrosion rate of rebar's encased under concrete can be measured using electrical impedance measurement [8].

Carbonation of concrete can be explained as the process by which atmospheric carbon di oxide $\left(\mathrm{CO}_{2}\right)$ in presence of moisture changes into dilute carbonic acid $\left(\mathrm{HCO}_{3}\right)$. It attacks on normal system of concrete and reduces alkalinity which provides protection to the reinforcement in RCC. This process is responsible for corrosion of reinforcement.

Dr Rajesh Kumar Tripathi is Professor with Department of Civil Engineering National Institute of Technology Raipur, India*rajesh_tripathi64@yahoo.co.in

Sr Ram Krisha Mishra is Research Scholar with Department of Civil Engineering National Institute of Technology Raipur, India
This work may justify the use of ponded ash in concrete suitable for the areas around thermal power plants. There are no any literatures available on carbonation exposer by replacement of fine aggregate with pond ash as per knowledge of authors. Hence, this work gives courage to work on sustainable construction.

\section{MEthodology}

\section{A. Material characterization}

OPC confirming to ASTM C 150-02 (ASTM 202e) [9]was used as cement. The fine aggregates were natural river sand with specific gravity 2.55 , water absorption $1.01 \%$, fineness modulus 2.84 and PA with specific gravity 2.02, water absorption $2.29 \%$ and fineness modulus 2.7 confirming to Zone 2 of BS 882 [10]. The coarse aggregates were nominal maximum size of $20 \mathrm{~mm}$ with specific gravity 2.73 , water absorption $0.56 \%$ and fineness modulus 7.17 used in this work confirming to BIS 2386 (III)-1963 [11].

\section{B. Experimental programme}

All the mixes were designed as per BIS 10262-2009[12] and designated as shown in table 1.

TABLE 1

CONCRETE MIX PROPORTIONS

\begin{tabular}{|c|c|c|c|c|c|c|c|}
\hline \multirow{3}{*}{\multicolumn{2}{|c|}{$\begin{array}{l}\text { Mix } \\
\text { No }\end{array}$}} & \multirow{3}{*}{$\begin{array}{l}\text { Mix } \\
\text { Type }\end{array}$} & \multirow{3}{*}{ /c } & \multirow{3}{*}{$\begin{array}{l}\mathrm{Ce} \\
\text { ment } \\
(\mathrm{kg} / \\
\left.\mathrm{m}^{3}\right)^{(}\end{array}$} & \multirow{2}{*}{\multicolumn{2}{|c|}{$\begin{array}{c}\text { Fine } \\
\text { Aggregate }\left(\mathrm{kg} / \mathrm{m}^{3}\right)\end{array}$}} & \multirow{3}{*}{$\begin{array}{r}\text { Coarse } \\
\text { Aggregate } \\
\quad\left(\mathrm{kg} / \mathrm{m}^{3}\right. \\
\end{array}$} \\
\hline & & & & & & & \\
\hline & & & & & \multicolumn{2}{|l|}{ d } & \\
\hline & $\mathrm{OPC}$ & $\mathrm{OPC}$ & 0 & 350 & 714 & - & 1142 \\
\hline 55 & & SA & .55 & & & & \\
\hline & OPCP & OPC & 0 & 350 & 316 & 31 & 1142 \\
\hline 55 & & $(\mathrm{PA}+\mathrm{SA})$ & .55 & & & 6 & \\
\hline & OPCP & OPC & 0 & 384 & 311 & 31 & 1124 \\
\hline 50 & & $(\mathrm{PA}+\mathrm{SA})$ & .50 & & & 1 & \\
\hline & OPCP & OPC & 0 & 427 & 305 & 30 & 1100 \\
\hline 45 & & $(\mathrm{PA}+\mathrm{SA})$ & .45 & & & 5 & \\
\hline
\end{tabular}

All the mixes were prepared using lab purpose concrete

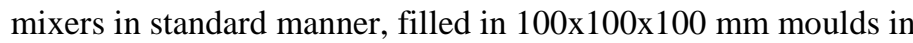
three layers and vibrated on vibrating table maintaining similar atmospheric condition. After $24 \mathrm{hrs}$ of casting samples were demoulded and kept for 28 days submerged curing in tank. Cubes were stored in controlled laboratory room, maintaining 
temperature range $27 \pm 2^{\circ} \mathrm{C}$ and $65 \pm 5 \%$ relative humidity for further testing after removal from curing tank. After 15 days of stabilization [13] three samples of each mix were kept in accelerated carbonation chamber for four month exposer in controlled environment of $10 \% \mathrm{CO}_{2}, 27 \pm 2^{\circ} \mathrm{C}$ temperature and $65 \pm 5 \%$ relative humidity. The results of carbonated concrete is compared with non carbonated concrete of same duration (i.e. $0.25,1,2$, 3and 4 months) from the date of $\mathrm{CO}_{2}$ exposer during testing of compressive strength and electrical resistivity. Carbonation depths were determined by spraying phenopthelene indicator as per RILEM CPC 18 [14] on freshly broken cubes through compression testing machine. Electrical resistivity measurements were taken before strength test on saturated surface dry samples as per guideline of Giatec RCON2 [15].

\section{RESULTS AND DISCUSSIONS}

\section{A. Compressive strength}

Compressive strength test of carbonated concrete after 1 to 4 month were tested along with non carbonated concrete sample of similar duration. Figure 1 shows relation between average compressive strength of non carbonated and carbonated concrete. The variation in compressive strength compared with non carbonated control concrete is shown in figure 2 .

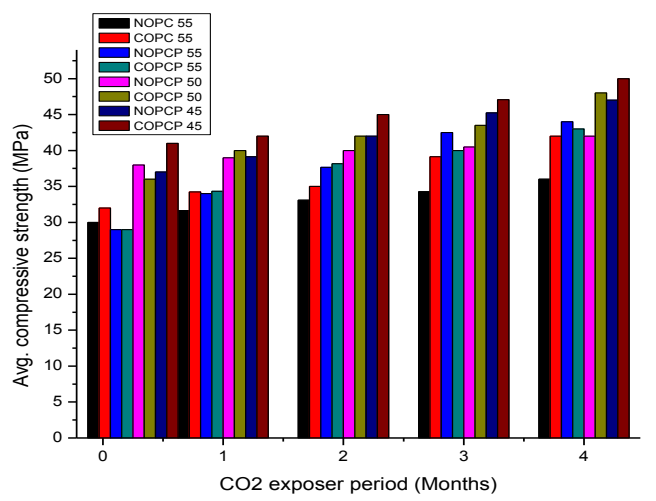

Fig. 1 Relation between average compressive strength of non carbonated and carbonated concrete.

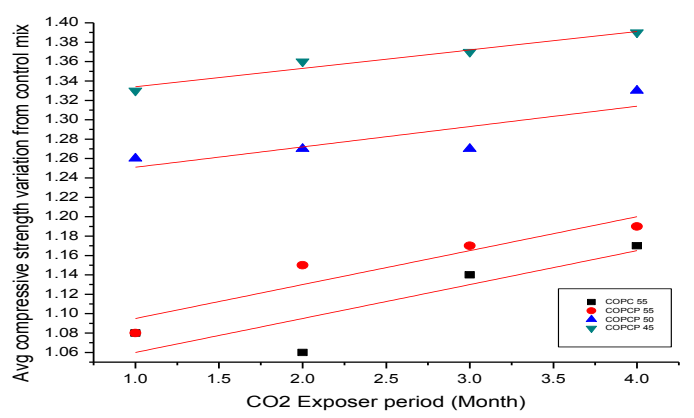

Fig. 2 The variation in compressive strength compared with non carbonated control concrete.

It is observed that carbonated sample shows higher compressive strength than non carbonated sample concrete. The variation in strength is ranges between $7 \%$ in higher water/cement ratio to $35 \%$ in lower w/c ratio, in the samples with pond ash as fine aggregate replacement.

The $\mathrm{R}^{2}$ value in the range $0.88 \%$ to $0.94 \%$ indicates strong correlation with the obtained results.

The increase in strength is due to the formation of solid calcium carbonate in the process of carbonation on replacement of calcium hydroxide.

This is similar to the results obtained by many researchers $[5,7,13$ and 16].

\section{B. Electrical resistivity}

Average electrical resistivity of concrete in non carbonated and carbonated stage is shown in figure 3 . It is noted that carbonated electrical resistivity is very high on comparison with non carbonated control mix shows (in figure 4) 2.2 times to 3.4 times in control mix in carbonated concrete upto $4^{\text {th }}$ month in very fast manner with $\mathrm{R}^{2}$ value of 0.88 . Concrete with low water cement ratio shows increment in the range 3.5 to 3.9 times giving $\mathrm{R}^{2}$ value of 0.87 . However, other two mixes gives non relevant statistical value hence discarded.

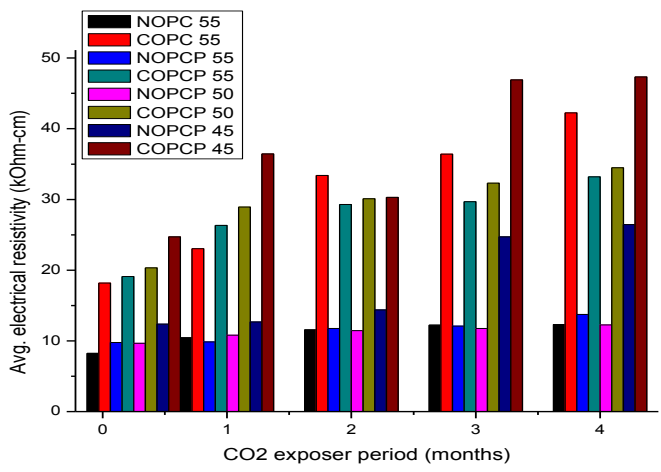

Fig. 3 Relation between carbonated and non carbonated concrete

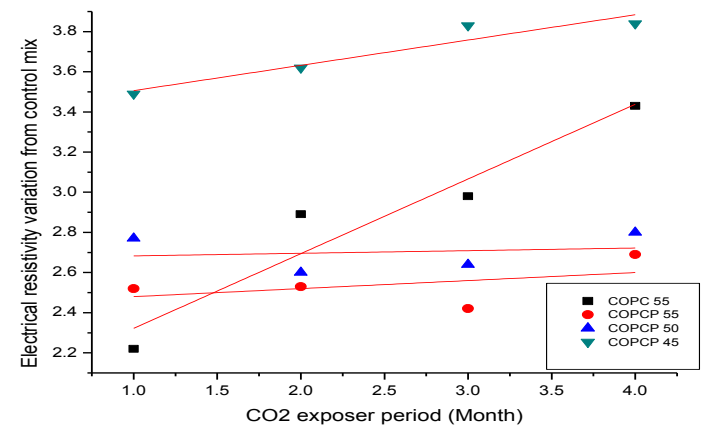

Fig. 4 Variation of electrical resistivity of carbonated concrete on comparison with non carbonated control mix.

Looking to the obtained results of bulk electrical resistivity of concrete and relation with chloride permeability as in Table 2 we find that even the results of non carbonated concrete are showing moderate to less permeability for chloride penetration [17].

Pond ashes in concrete filled the pores and hence make the concrete more durable in lower $w / c$ ratio sample. 
TABLE II

RAPID CHLORIDE PERMEABILITY AND BULK ELECTRICAL RESISTIVITY

\begin{tabular}{|c|c|c|}
\hline $\begin{array}{c}\text { Chloride } \\
\text { penetration }\end{array}$ & $\begin{array}{c}56 \text { Days rapid chloride } \\
\text { permeability } \text { Charge passed a } \\
\text { per ASTM C } 1202 \text { (Coulombs) }\end{array}$ & $\begin{array}{l}28 \text { Days Bulk } \\
\text { electrical resistivity } \\
\text { of standard concrete } \\
(\mathrm{k} \Omega . \mathrm{cm})\end{array}$ \\
\hline High & $>4000$ & $<5$ \\
\hline Moderate & $2000-4000$ & $5-10$ \\
\hline Low & $1000-2000$ & $10-20$ \\
\hline Very & $100-1000$ & $20-200$ \\
\hline Low & & \\
\hline $\mathrm{e}^{\text {Negligibl }}$ & $<100$ & $>200$ \\
\hline
\end{tabular}

\section{Carbonation depth}

The figure 5 shows carbonation depth at various ages for the given concrete. On observation of the results of carbonation depth it is clear that carbonation depth increases in concrete with pond ash which is matching with the results as in figure 1 and 3 i.e., compressive strength and bulk electrical resistivity is highest in carbonated concrete.

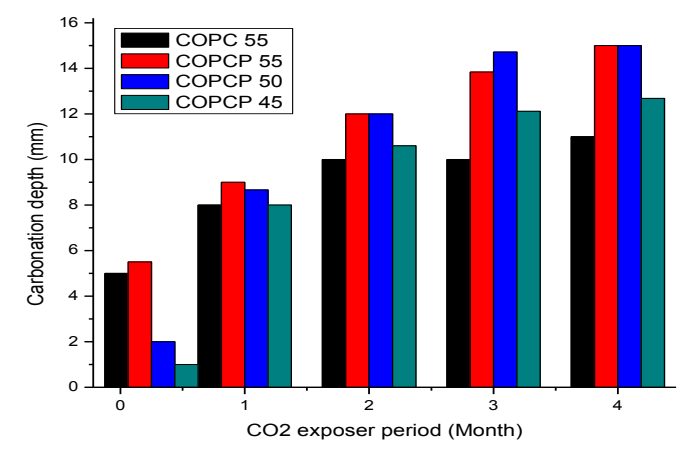

Fig. 5 Carbonation depths at various ages for the given concrete.

\section{Morphological detailing}

Field Emission Gun Scanning Electron Microscopy (FEG SEM) results of the concrete with PA in carbonated and noncarbonated conditions are as under in figure 6 and 7;

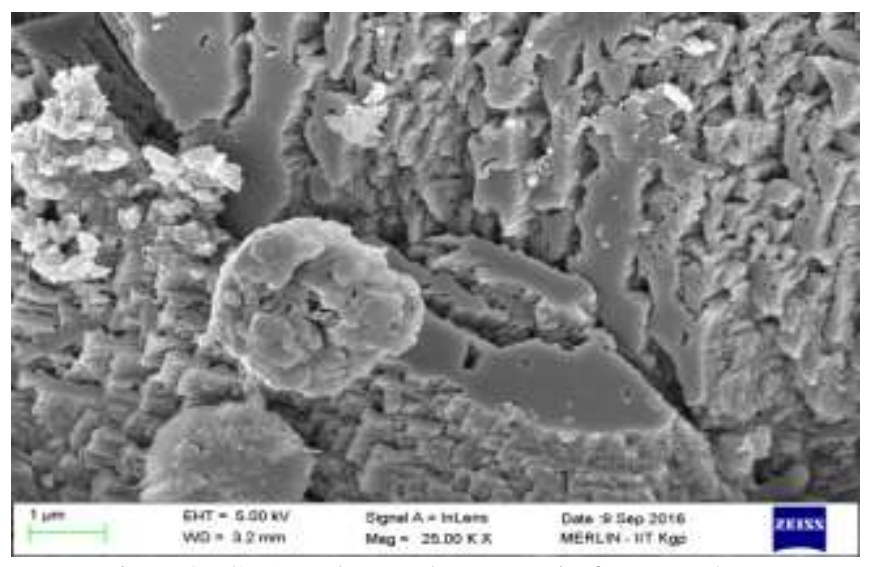

Fig. 6 OPC PA carbonated concrete in four months

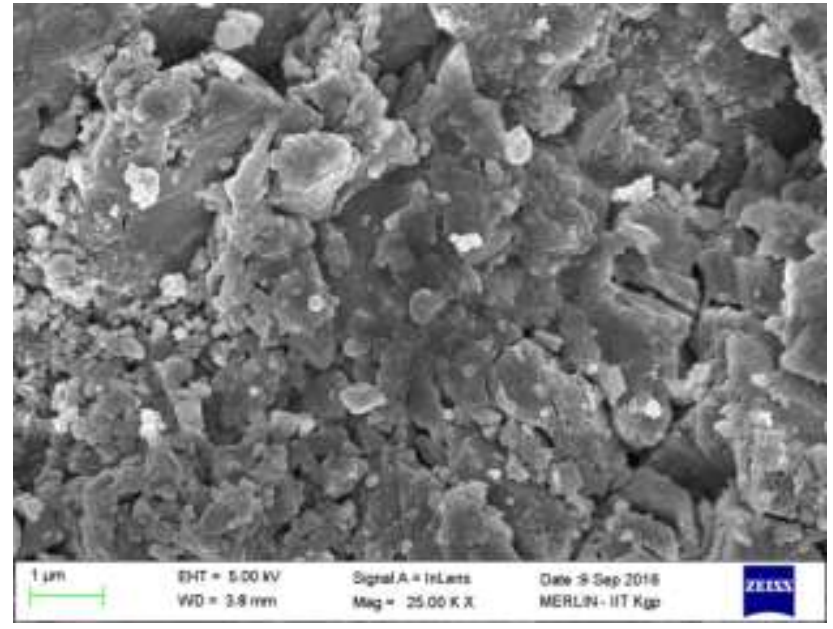

Fig. 7 OPC SA carbonated concrete in four months

\section{CONCLUSIONS}

Utilization of Pond Ash as fine aggregate replacement can be a better option for sustainable construction with following benefits;

$>$ Higher compressive strength

$>$ Higher bulk electrical resistivity

$>$ Less permeable concrete

$>$ Denser structure is the result of PA inclusion Fig 6, and 7.

$>$ Economy in construction as pond ash is available as waste material needs disposal to save the environment'

\section{ABBREVIATIONS}

NOPC and COPC : Non Carbonated and carbonated concrete

NOPCP 55 and COPCP 55 :Non Carbonated and carbonated concrete with $\mathrm{w} / \mathrm{c}$ ratio 0.55 with $\mathrm{PA}$

NOPCP 50 and COPCP 50: Non Carbonated and carbonated concrete with $\mathrm{w} / \mathrm{c}$ ratio 0.50 with $\mathrm{PA}$

NOPCP 45 and COPCP 45 : Non Carbonated and carbonated concrete with $\mathrm{w} / \mathrm{c}$ ratio 0.45 with $\mathrm{PA}$

\section{ACKNOWLEDGMENT}

Authors are highly acknowledge the financial support given by Ministry of Human Resource Development New Delhi under CPDA and N.I.T Raipur Management for permitting to attend and present the paper in this conference.

\section{REFERENCES}

[1] Mangaraj B.E. and Krishanmoorthy S. (1993) "Use of Ponded Fly Ash as Part Replacement of Fine Aggregate in Cement Mortar and Concrete and Influence on Workability" Indian concrete Journal.

[2] Kalgal M. R., Pranesh R. N and Ravi Shankars (2007) "Strength and durability of concrete with pond ash as fine aggregate" The Indian concrete journal volume 81 No.3 pp7-11.

[3] Pofale A. D and Deo S. V. (2008), compressive strength comparison of OPC and PPC mortar with and without replacement of Natural sand by Fly Ash National conference ETC-ID, N.I.T. Raipur

[4] Mishra R. K. and Tripathi R. K.,( 2015) "Mechanical properties of concrete on partial replacement of natural sand with alternative materials" Proceedings of 4th Asian Conference on Ecstasy in concrete, ICI-ACECON. Science City, Kolkata, India. 8-10, October, 1: 279- 287 ISBN 978-81-920623-3-4 
[5] Mishra R. K., Tripathi R. K. and Dubey V.,(2016) Early age shrinkage pattern of concrete on replacement of fine aggregate with industrial by product, Journal of radiation research and applied sciences. 9, pp386391.

[6] Ranganath R. V., Bhattachajee B. and Krishnamurthy, S. (1998), Influence Of size fraction as ponded ash on its pozzolanic activity. eprint.iitd.ac.in/ bitstream/ 2074/561/1.

[7] Jack M. Chi, Ran Huang, and C. C. Yang, (2002) Effects of Carbonation on Mechanical Properties and Durability Of Concrete Using Accelerated Testing Method, Journal of Marine Science and Technology, Vol. 10, No. 1, pp. 14-20.

[8] Glass G. K., Page C. L. and Short N. R., (1991) Factors Affecting the Corrosion Rate of Steel in Carbonated Mortars, Corrosion Science, Vol. 32, No. 12, pp. 1283-1294.

[9] ASTM. (2002e) Standard specification for portland cement. C 150-02, West Conshohocken, PA.

[10] British Standards Institution. (1992) Specification for aggregates from natural source for concrete. BS 882, London.

[11] BIS 2386(part 3)-1963 Indian Standard methods of test for aggregates for concrete, Bureau of Indian Standards Manak Bhavan, 9 Bahadur Shah ZafarMarg New Delhi 110002.

[12] BIS 10262-2009 Indian Standard method of concrete mix design" Bureau of Indian Standards, New Delhi, 2009.

[13] Sulapha P., Wong S. F., Wee T. H. and Swaddiwudhipong, S. (2003). Carbonation of concrete containing mineral admixtures. J. Mater. Civ. Eng., 15(2), pp134-143.

[14] RILEM Recommendations. (1988). "CPC-18 measurement of hardenedconcrete carbonation depth.” Mater. Struct., 21(6), pp453-455.

[15] GiatecRCON2 http://www.giatecscientific.com/

[16] Das B. B. and Pandey S. P. (2011), Studies on influence of fineness of fly ash on the carbonation and electrical conductivity of concrete. J. Mater. Civ. Eng., 23(9), pp1365-1368.

[17] Shane J. D., Aldea C. M. Bouxsein N. F. Mason, T.O., Jenning H. M., Shaw, S.P. (1999)," Microstructural and pore solution changes induced by rapid chloride permeability test measured by impedance spectroscopy", Concrete Science and Engineering, Vol. 1, pp. 110-119. 